\title{
Implementing Cultural Diversity Within and Outside the European Union: A Test for the Delineation of Competences in Cultural Matters?
}

Laura-Maria Crăciunean*

\section{Abstract}

The purpose of this paper is to evaluate the European Union's (EU) involvement in the protection of cultural diversity, both within and outside the EU, after the entering into force of the Lisbon Treaty, in 2009, and the adoption of the UNESCO Convention of 2005. The author examines whether this involvement can be depicted in concrete measures aiming at the effective internal and external implementation of the provisions of the UNESCO Convention of 2005. The author further seeks to analyse whether the entailed consequences of EU's actions, including the erosion of the Member State's competences in the cultural field, was translated in concrete measures or if it still remains at the political discourse level.

Keywords: Culture, Cultural Diversity, European Union, UNESCO, United in Diversity

\section{Introduction}

The democratic deficit of the EU, one of the main issues of debate in relation with the legitimacy of the European project, is also

*Associate Professor, Faculty of Law, Lucian Blaga University of Sibiu, Romania; Independent Expert, U.N. Human Rights Council Advisory Committee (2014-2017); laura.craciunean@gmail.com. 
translated, in a wider context, into a cultural one. Even though, culture is seen as a premise and a common basis in any identity building process, at the EU level a common European culture is still far from being a reality. The European project itself was imagined, basically, as an economic one. In terms of legal regulation this approach was translated in the way in which the specific competences of EU's and its Member States were ascribed, by the $\mathrm{EC}^{\prime} \mathrm{s}$ (now, the EU's) ${ }^{1}$ founding treaties.

Culture was considered to be a sensitive matter for both the EU, in the area of European integration, and for its Member States, because of its central role in the formation of state and local identity. As a consequence, the compromise formula was the one of giving to the EU rather narrow cultural competences, i.e. competences which were meant to complement the ones of its Member States. However, over time, the EU has asserted, through treaty-making, legislative and administrative processes, for more competences in cultural matters despite the reluctance of the latter. Thus, the European cultural policies during the last decades are seen as a means through which the EU actors/institutions have attempted to enlarge the scope of the EU powers beyond what the European project was originally imagined to be. They seem to have envisaged a step by step approach which was meant to culturally legitimize this economic project, by conferring to it, both a social and a cultural dimension.

In this context, the adoption, of the UNESCO Universal Declaration on Cultural Diversity (UNESCO Declaration of 2001), on November 2 , 2001, not only bears great relevance for the cultural field but also has a symbolic importance in the evolution of general international law. It constitutes a relevant 'political turn' 2 as it transforms cultural diversity from an obstacle, a brake which was set into the way of progress, development or democracy, into a source and

${ }^{1}$ (Since December 1, 2009; the date of the entering into force of the Lisbon Treaty, the European Community (EC) was dissolved into the European Union).

2P. Meyer-Bisch, La centralité des droits culturels, points de contact entre diversité et droits de l'homme in Annuaire International Des Droits de L'homme 32 Vol. III/2008, Bruylant, Bruxelles, 2008. 
resource of the very same values. The UNESCO Declaration of 2001 was followed, only four years later, in 2005, by the UNESCO Convention on the Protection and Promotion of the Diversity of Cultural Expressions (the Convention), which entered into force on March 18, 2007 , being, thus, the first legally binding instrument in the field of cultural diversity. Moreover, the EU became party to this Convention in its own name and urged its Member States to follow the same approach. Although the Convention reaffirms the sovereignty of States Parties over cultural issues, from the perspective of EU' s Member States, EU's involvement and its subsequent actions are to be seen as controversial.

Firstly, when looked at it within the EU, through the lens of the conferral, ${ }^{3}$ proportionality, ${ }^{4}$ subsidiarity ${ }^{5}$ and shared competences principles, although the EU has no cultural competence, there are several provisions that can be seen as creating a concrete legal basis for the undertaking of cultural-specific actions at the EU level. This is reflected in Article 2 (5), 6 (c) and 167 (1) and (5) of the Treaty on the Functioning of European Union (TFEU). Moreover, at the political discourse level, the EU portrays itself as the main promoter of its Member States' cultural diversity. This approach may lead, inter alia, to debates on the possible erosion of the

${ }^{3}$ European Union, Treaty on European Union (Consolidated Version), Treaty of Maastricht arts. 4, 5(1) \& (2), 7 February 1992, Official Journal of the European Communities C 325/5; 24 December 2002 available at http:/ / www.refworld.org/docid/3ae6b39218.html (In accordance with the principle of conferral, the EU has only those competences conferred upon it by the Treaties, in accordance with articles 4 and 5 (1) and (2) of the TEU).

4 (The proportionality principle states that the exercise of EU' S competences may not exceed what is necessary to achieve the objectives of the Treaties, in accordance with articles 4 and 5 (1) and (2)of the TEU).

${ }^{5}$ European Union, Treaty on European Union (Consolidated Version), Treaty of Maastricht arts. 5(1) \& (3), 7 February 1992, Official Journal of the European Communities C 325/5; 24 December 2002 available at http://www.refworld.org/docid/3ae6b39218.html (The subsidiarity principle, in relation to the shared competences, states that the EU may intervene only if it is capable of acting more effectively than its Member States). 
sovereign rights of the Member States over cultural issues with the consequence of enhancing its own cultural competence.

Secondly, with respect to EU's external relations, several dispositions are also relevant, namely: Article 3 (5) and 21 of the Treaty on European Union (TEU), Article 167 of the TFEU (former article 151 of the TEC), 207 and 216 of the TFEU. A general reading of these provisions illustrate that in its external relations, with third countries, the EU aspires to portray itself as the main promoter of cultural diversity at the global level. Moreover, it has integrated the value of cultural diversity in its external political discourse and has even created its own 'export model', referred here, as 'the united in diversity model'.

The purpose of this paper is to evaluate whether the involvement of EU in cultural issues, (both within and outside the EU), has been limited to the political discourse level, or whether it has gone beyond that level. Can this involvement be depicted in concrete measures aiming at effective internal and external implementation of the Convention's provisions, with all entailed consequences, including the erosion of its Member States' competences in the cultural field?

In dealing with the above mentioned issues, the second part of this article constitutes an overview of the theoretical opinions on the issue. In the third part, the EU's role and involvement in the making and adoption of the Convention and the relevance of its actions in relation to the political and practical, internal and external dimensions, is discussed. Finally, the conclusion of the article evaluates the impact of the Convention on both internal and external fields of action of the EU.

For the purposes of this paper, certain terminological clarifications are also needed. Firstly, the understanding of a model is not that of a simple shape, that limits itself to reproducing the characteristics of the original, thus creating many identical objects. A model also has a quality dimension. Thus, a model is "a person, object, a work or a construction, which by value or qualities could serve as an 
example". 6 Secondly, by 'the united in diversity model' it is intended to be the EU model, even though a true European model of approaching cultural diversity is the result of the condensed and interrelated work of the European Union, Council of Europe and the Organization for the Security and Cooperation in Europe.

\section{The European Union and the UNESCO Convention of 2005: Theoretical Approaches}

At the theoretical level, EC/EU's involvement, in both its internal and external dimensions, and especially the fact that cultural diversity became an indispensable element of EU's external politics, has fueled discourses, debates, controversies and opinions that can be summarized as follows.

Departing from the legal framework, namely Art. 6 of the TFEU, Toggenburg stresses that the EU' $\mathrm{s}$ competences in the cultural field are limited to support, coordination and complementary actions. Thus, EC/EU' s involvement in a field that traditionally belongs to its Member States, namely culture, is seen as the basis for the discourse affirming that "the cultural sovereignty of the EU Member States is eroded. So, what the EU is doing, is meant to widen its own competences, on the cultural field, with the consequence of limiting the ones of its Member States" ${ }^{\prime 7}$

Bruno de Witte, while admitting that the EC's implication during the negotiation of the Convention, can be seen as 'novel way of negotiating a treaty', considers that the position on the matter was not at all surprising, being just 'the most visible way' of $\mathrm{EU}^{\prime} \mathrm{s}$ action in the cultural field. ${ }^{8}$ Thus, even if the main responsibility to

${ }^{6}$ I. Coteanu, L. Mares, , L. Avram (eds.), Dicționarul Explicativ al Limbii Române (DEX) 644 Bucureşti, Univers Enciclopedic, 1996.

${ }^{7}$ G. Toggenburg, The Debate on European Values an the Case of Cultural Diversity 1/2004, 24-25 http://www.eurac.edu/en/research/autonomies/minrig/publications /Pages/European-Autonomy-and-Diversity-Papers\%28EDAP\%29.aspx.

8 B. De Witte, The Value of Cultural Diversity in European Union Law, in PROTECTION OF CUlTURAL DiVERSITY FROM A EUROPEAN AND 
conduct cultural policies and protect cultural diversity remains in the field of action of its Member States, EC's/EU's constant actions prove that the existence and the scope of these legal competences do not impede the furtherance of the cultural goals of the UNESCO Convention, including a possible extension of EU's competences in the cultural field. But, as pointed out by de Witte, "cultural diversity may be as much about increasing the variety of cultural options for individual citizens across Europe as it is about securing the cultural identity of nations and regions. In fact, these two rival interpretations of the concept of cultural diversity are crucial to the current impact of European Union policies (...) respectively, if the EU privileges one reading over the other depending on the particular policy context". ${ }^{9}$

A third opinion, ${ }^{10}$ that I also share, with some amendments and comments, is departing from the wide scope of application of the UNESCO Convention of 2005. From this point of view, the EU did not have any other choice but to be involved in the process. The main arguments that Psychogiopoulou mentions in this regard are: i. the transversal effects of culture, i.e. effects which are not necessarily covered by what we refer to as 'cultural policies'; ii. the fact that culture could not be addressed in vacuum so, policies and measures taken in other fields where the EU has exclusive competences (for example, trade) could have effects or implications on the cultural field as well. Moreover, "EU cultural action is not simply derived from Article 167 of TFEU; it also originates in other provisions of the TFEU that can be used for the attainment of cultural objectives, combined with other legitimate EU policy goals. But beyond this, the fervent support offered by the EC/EU to the UNESCO Convention of 2005 unveils the ambitious agenda developed by the European institutions with regard to culture in

International Perspective 219 (H. Schneider \& P. van den Bossche eds., Antwerpen-Portland, Intersentia, 2008).

9 Id. at 223-224.

10 E. Psychogiopoulou, The Convention on the Diversity of Cultural Expressions and the European Union. The Quest for Competence and Implementation, in THE UNESCO CONVENTION ON THE DIVERSITY OF CULTURAL EXPRESSIONS: A TALE OF FragMENTATION IN INTERNATIONAL LAW 365-394 (T. Kono, S. Van Uytsel eds., Cambridge, Portland, 2012). 
recent years". ${ }^{11}$ In other words, "through the Convention on the Diversity of Cultural Expressions the EU aspires to portray itself as a staunch promoter of the cultural diversity of its Member States and a world actor in favor of cultural rapprochement" ${ }^{12}$

Despite the political discourses affirming that the fundamental principle on which the Convention rests upon is the one of states' sovereignty over their cultural issues, it is precisely this cultural sovereignty that can be affected when it comes to states that are also members of the EU (an international cooperation organization in which members' sovereignty is limited in many aspects, in order to enable the organization to pursue its own objectives, namely the integration of its members). Any integration process presupposes certain common values, either pre-existent or created alongside. These tensions, between common values and cultural diversity, are expressed in Article 3 of the TEU which states that "The Union shall respect its rich cultural and linguistic diversity and shall ensure that Europe's cultural heritage is safeguarded and enhanced". Furthermore, Article 167 of TFEU states that "The Union shall contribute to the flourishing of its Member States cultures, respecting their national and regional diversity, while pointing out their common cultural heritage".

The aforementioned texts illustrate that the potential centrifugal feature of cultural diversity is the European polity. Alternatively, as Shore puts it: "(...) there is a renewed interest in the cultural aspects of integration. EU policy-makers therefore decided that more 'concrete measures' were needed to enhance the image and identity of the Community through information campaigns and a series of symbolic initiatives. The way these ideas were translated into

${ }^{11}$ E. Psychogiopoulou, The Convention on the Diversity of Cultural Expressions and the European Union. The Quest for Competence and Implementation, in THE UNESCO CONVENTION ON THE DIVERSITY OF CULTURAL EXPRESSIONS: A TALE OF FRAGMENTATION IN INTERNATIONAL LAW 371-372 (T. Kono, S. Van Uytsel eds., Cambridge, Portland, 2012). 12 Id. at 393. 
policy offer insights into the hidden history of European integration". ${ }^{13}$

Following the same rationale, Von Bogdandy equated the relationship between the EU law and general international law with the phrase 'elements of a beautiful friendship' 14 and evaluated it as a 'win-win' relation. General international law offers to the EU institutions the instruments for achieving the European unity but, at the same time, the EU serves the implementation of the international law of cultural diversity. As Von Bogdandy suggests, the EU is using general international law to enter fields that traditionally belonged to its Members States in this particular case, being culture and it serves the implementation of the international law of cultural diversity. ${ }^{15}$

So, the question arises as to whether the EU can work for the protection of cultural diversity if it wishes to do so. If so, which approach will be preferred by the EU? Has the UNESCO Convention helped the EU in its integration mission, in the last ten years since its entry into force? It also poses as question as to whether the cultural sovereignty of EU Member States is progressively eroding while it seeks to serve this common goal. A short overview of the political and practical, internal and external dimensions of this relation will be useful in order to find some of the answers.

\section{The European Union and the UNESCO Convention of 2005: Political and Practical, Internal and External Dimensions}

The EU, as any other political and/or legal construction, has certain fundamental values that constitute its basis and which can be easily

${ }^{13} \mathrm{C}$. Shore, European Union and the Politics of Culture, THE BRUGES GROUP, 2001

http://www.brugesgroup.com/mediacentre/index.live?article=13\#cult ure.

14 A. von Bogandy, The European Union as Situation, Executive, and Promoter of the International Law of Cultural Diversity - Elements of a Beautiful Friendship in European Journal of International Law 19(2) EU. J. INT'L L. 2412008.

15 Id. at 243-245. 
identified in its founding treaties. Moreover, it carries out a series of symbolic initiatives that are meant to promote and enhance these values. One of these values appears to be that of cultural diversity, in both its inter-state and intra-state dimensions. If this particular value is viewed through the lens of $\mathrm{EU}^{\prime} \mathrm{s}$ motto, 'united in diversity' there are very interesting interactions and consequences that emerge from the same.

As regards respecting the inter-state cultural diversity is concerned, this principle is reflected, in an implicit manner, in a series of primary law sources of the EU. It is also present in the existence and regulation of the subsidiarity principle, the competence sharing pattern between the EU and its Member States and in the decision making process at the EU level. All the above mentioned illustrate a certain preoccupation of the EU for the protection of the cultural diversity of its Member States. According to the classical approach to the issue, the EU seems to appreciate the fact that no matter how far it will go ahead with the economic and even political integration, the price to pay for this achievement should not be at the cost of its Member States' cultural diversity.

As far as the intra-state cultural diversity is concerned, the classical approach places all culture related issues on the exclusive and sovereign competence of each state. Even if Article $2(2)^{16}$ of the Convention reaffirms the principle of sovereignty, thus, confirming this approach, there are some supplementary implications, that arise for consideration, when it comes to states that are also members of European Union.

After 2007, basically two developments took place that could question this classical approach, namely (i) the involvement of the EU (at that time the EC) in the drafting, negotiation and adoption of the Convention and (ii) the adoption and entering into force, in December 2009, of the Lisbon Treaty. In a way these two developments can be seen as interrelated, as both treaties, reflect

16 ("States have, in accordance with the Charter of the United Nations and the principles of international law, the sovereign right to adopt measures and policies to protect and promote the diversity of cultural expressions within their territory"). 
the general trend followed in international law, with respect to protection of cultural diversity. ${ }^{17}$

On one hand, according to the Convention's dispositions, not only states parties, but also the EU, are responsible within theirs respective territories, for the protection and safeguarding of cultural diversity whereas on the other, several dispositions of the Lisbon Treaty facilitate EU's involvement in the cultural field, especially through political documents and recommendations. This helps in the exercising of EU's support, coordination and complementary competences, in accordance with Article 2 (5) and 6 of the TFEU. Seen from this perspective, it appears that the 'exclusive' competence of the EU's Member States, in cultural matters, is actually under the 'attentive supervision' of the EU owing to its responsibility towards the promotion and protection of cultural diversity within its own borders. This approach is meant to erode, on a step-by-step rationale, the exclusive competence of its Members States in the cultural field.

This 'step by step rationale' could be easily traced back to the developments in the 1980s and the '90s. Although EC had adopted some soft law documents emphasizing the need for 'European common values' (The Copenhagen Declaration on the European Identity, 1973 and The European Commission Communication on the Community Action in the Cultural Sector, 1982), culture was considered to be a field of action exclusively belonging to the sovereign states' competence. However, in 1992, the Maastricht Treaty transformed culture in the EC's general policy fields of action, thereby giving to the EC institutions a true cultural mandate. This mandate was, nevertheless, supposed to take due account of the subsidiarity principle and maintain a balance between the respect for intrastate cultural diversity and the need to bring into light the EU Member States' 'European common heritage' (Article 151 (1) of the TEU). Subsequent steps in this direction, were made through the Charter of Fundamental Rights

17 M. Keating, Culture and Social Science in APPROACHES AND Methodologies In The SOCial Sciences: A Pluralist PersPective 102103(Cambridge University Press, 2008). 
of the EU (2000) ${ }^{18}$ and the Constitutional Treaty (2004). ${ }^{19}$ After the adoption and the entering into force of the Lisbon Treaty, this approach continued and was confirmed by a series of provisions contained in the TFEU (especially, Art. 167, 2 (5), 6 (c), 13, or 207) and in TEU (Preamble, Article 2, 3 (3), 4 (2), 6 (3) or 21).

When it comes to ascertaining the relationship between the EU law and the Convention, with respect to the implementation of the Convention at the EU level, 'the came into being' provision of this Convention has to be considered. During the years, that preceded the adoption of the Convention, the EC (now, the EU) was granted 'enhanced observer status' and got involved, as an active player, not only in the drafting and negotiation stages but also in the ratification process that followed. Besides putting forth proposals or amendments and participating in working groups, formal and informal meetings; the EC (EU) became party to the Convention, in its own name. This could be laid down in a sequential manner.

Firstly, the EU welcomed the adoption, of the UNESCO Universal Declaration on Cultural Diversity, in 2001 and encouraged and stressed that UNESCO should continue this path and adopt a legally binding document. In the Communication from the Commission to the Council and European Parliament, the document titled 'Towards an International Instrument on Cultural Diversity', 20 was addressed to the European Parliament and

${ }^{18}$ European Union, Charter of Fundamental Rights of the European Union, 26 October 2012, 2012/C 326/02, available

at: http://www.refworld.org/docid/3ae6b3b70.html.

19 European Union, Treaty Establishing a Constitution for Europe, 16 December 2004, Official Journal of the European Union, C310, 16 December 2004, available at: http://www.refworld.org/docid/41d162834.html (Signed on the 29th of October 2004 but has not been ratified by all EU Member States. It was replaced, in 2009, by the Lisbon Treaty. Its complete title is the Treaty Establishing a Constitution for Europe (TCE), commonly referred to as the European Constitution or the Constitutional Treaty).

${ }^{20}$ Communication from the Commission to the Council and the European Parliament, Towards An International Instrument On Cultural Diversity, COM/2003/0520, 2003 http://eur- 
Council, the Commission also expressed a view on the content of the future document; "a future legally binding document on this matter should create a forum for states to debate on their cultural policies and an institutional framework to watch for the universal status of cultural diversity and to involve states in the elaboration and identification of international standards related to cultural diversity". The EC, through the European Commission, expressed the view that it should be involved in the negotiations because such an instrument is very likely to affect $l^{\prime}$ acquis communautaire, ${ }^{21}$ as it will not address culture in vacuum.

Secondly, the EC asked to participate in its own name, alongside the representatives of its Member States, to ensure that the final text of the future convention will allow the Community (now, the EU) to be a separate contracting party. As culture is a domain that traditionally falls under the sovereign competence of states, and it being a delicate field, the European Council adopted the Code of Conduct between the Council, the Member States and the Commission on UNESCO Negotiation on the Draft Convention on the Protection of the Diversity of Cultural Expressions, 2005, 22 establishing the manner in which the negotiations were to be conducted by each party.

Moreover, after the adoption of the Convention, the EU acted as its main supporter and promoter. It urged its Members States to become parties to the Convention so as to enable the fulfillment of the obligations that arise from the text of the Convention and to exercise the assigned competences, especially with respect to the shared obligations. This approach proved to be very convincing.

lex.europa.eu/LexUriServ/LexUriServ.do?uri=CELEX:52003DC0520:EN :HTML

${ }^{21}$ L'acquis communautaire ( $f r$ ) is the accumulated legislation, legal acts, and court decisions which constitute the body of European Union law.

${ }^{22}$ (Council of the European Union (2005). Code of Conduct between the Council, the Member States and the Commission on the UNESCO Negotiations on the Draft Convention on the Protection of the Diversity of Cultural Expressions, EU Doc. 5768/05 of 31 st of January 2005). 
Today, 23 all the 28 Member States of EU are parties to the Convention, either by way of accession or ratification. Romania was the first European state to ratify the Convention in July 20, 2006 even though it was not a member of the EU at that time. Through these initiatives, the EU aspires to portray itself as the main promoter of the cultural diversity of its Member States.

When seen in relation with the EU law, the Convention is a mixed agreement but, undoubtedly, it is also a cultural one. Due to EU' s limited competences in the field of culture, the coming into being of this Convention, its promotion, by the EU as well as its future implementation, have fueled discourses about the widening of the $\mathrm{EU}^{\prime} \mathrm{s}$ cultural competences and consequentially the erosion of the national cultural sovereignty of EU's Member States. Moreover, as the Convention is not addressing culture in vacuum, it also affects a wide range of policy fields such as competition, trade, immigration, external relations, languages, education, human rights etc whereas the EU competences are wider. Thus, this horizontal effect gives to the EU the opportunity to intervene in the cultural field through stronger means of action. This raises questions not only in respect of the internal political discourse level but also on the effective implementation of the Convention at the EU level, on the means and results of such implementation.

At the political discourse level, there are a series of political documents listing, that the priority objectives of the EU are intercultural dialogue, the strengthening of cultural policies and programs that are executed for the general promotion of the Convention.

On the other hand, at the concrete level there are studies on the implementation of the Convention ${ }^{24}$ within the framework of

23 (The last EU member state to become a party to the UNESCO Convention of 2005 is Belgium, on the $9^{\text {th }}$ of August 2013, through ratification).

24 Directorate General for Internal Policies, European Parliament, Brussels, 2010, Report Implementing the UNESCO Convention of 2005 in the European Union (No.

IP/B/CULT/IC/2009_057)

http:/ / www.europarl.europa.eu/RegData/etudes/etudes/join/2010/4 38587/IPOL-CULT_ET\%282010\%29438587_EN.pdf. 
human rights policies in the European Union in relation to third countries (through international agreements containing formal clauses), 25 and also within the European Union, which argues on the lack of effectiveness of its present implementation and provides suggestions for the future steps to be. On a primary glance it is found that the Convention has more of an impact on the 'political discourse' than on the legislative process.

However, these studies also argue that the implementation of the Convention has to be understood as an ongoing process. There are also various methods through which the implementation can be done in the future. For example, through the EU judiciary, by means of consistent interpretation, as stated by European Court of Justice in cases like Commission $v$. Germany 26 and Hermes International v. FHT Marketing Choice BV. ${ }^{27}$ Another way of dealing with its implementation is through common actions and cooperation as stated by the ECJ in its famous opinion 1/94495: “(...) it is essential to ensure close cooperation between Member States and the Community institutions, both in the process of negotiation and conclusion and in the fulfillment of commitments entered into". The principle of cooperation is also expressed, in a general manner, under Article 4 (3) of the TEU. This text is consistently applied by the ECJ to mixed agreements and it is of real assistance as regards the implementation of the UNESCO Convention, 2005, as the provisions of the Convention cannot be invoked, as such, before the ECJ. So, the EU "can act for the protection of cultural diversity if it wishes to do so" but, on the other hand, it is for the EU to decide which of the two opposing readings of cultural diversity prevails. 28

Another step that the EU has taken is the one through which it is trying to transform cultural diversity into an indispensable element of its external politics, acting as a world actor in favor of cultural

${ }^{25}$ (For example: "The application of this Agreement shall fully take into account the principles of the UNESCO Convention on the protection and promotion of cultural expressions").

${ }^{26}$ European Court of Justice, Case 61/94, 1995 ECR I-3989.

${ }^{27}$ European Court of Justice, Case 53/96, 1998, ECR I-3603.

${ }^{28}$ de Witte, supra note 7 at 223-224. 
rapprochement. ${ }^{29}$ This approach should be looked at from two different dimensions: firstly, at the external political discourse level and secondly, at the concrete level, namely the effective implementation of the Convention in the EU' $s$ external agreements.

At the political discourse level the implications of the new Convention was acknowledged by the European Commission which, in its Communication dated May 10, 2007 on a European agenda for culture in a globalized world, stated that the entry into force of the Convention illustrates the new role of cultural diversity at the international level'. ${ }^{30}$ Moreover, in 2008, the external dimension of culture was made a priority, first by the Slovenian Presidency of the European Commission during the Ljubljana Conference and this was reiterated, a few months later, by the European Council itself in its efforts to promote the European Year of Intercultural Dialogue. ${ }^{31}$

With cultural diversity as a front runner, it appears that the EU has taken the chance of re-branding and has been trying to develop a model, namely 'the united in diversity model'. This model is promoted and reflected in all EU' s actions outside its borders. It could also be useful in the process of constructing the European identity; as far as this identity is understood as 'a sense of becoming, something nobody is simply by birth, because it is permanently in evolution'. ${ }^{32}$ This approach is reflected at the concrete level, in the EU's fundamental treaties. So, when it comes to effectiveness and means, again, the I considers that the EU has the means to act, especially after 2009, since the entering into force of the Lisbon Treaty.

${ }^{29}$ Psychogiopoulou, supra note 9 at 390-393

${ }^{30}$ Communication from the Commission to the European Parliament, the Council, the European Economic and Social Committee and the Committee of the Regions, European Agenda For Culture In A Globalizing World, 2007, http://eur-lex.europa.eu/legalcontent/EN/TXT/HTML/ ?uri=CELEX:52007DC0242\&from=EN.

31See Slovenian Presidency of the EU, 2008 http:/ / www. EU2008.si/ en/News

32 M. Sassatelli, Becoming Europeans: Cultural Identity And CulturAl POlicies 198 (Basingstoke, Palgrave Macmillan, 2009). 
After this date, the relation between the EU law and general international law has been equated by Von Bogdandy with the phrase 'elements of a beautiful friendship' 33 and evaluated as a 'win-win' relation as was discussed earlier in this paper. General international law offers to the EU institutions the instruments for achieving the European unity but, and correspondingly the EU serves the implementation of the international law of cultural diversity. As Von Bogdandy suggests, the EU is using general international law to enter fields that traditionally belonged to its Members States and it serves the implementation of the international law of cultural diversity. Following Von Bogdandy, the I argues that it does so by using and exporting its own model which has resulted from this successful relationship. The general international law will be of great help for the EU in order to achieve a superior level of unity among its Member States. In relation to this 'united in diversity' model, there are two issues of concern: firstly, the consequence of adopting such an approach over EU' $\mathrm{s}$ Member States' cultural sovereignty and secondly, what would entail if this model, is going be shaped, solely, through the involvement of loudspeaker rich democracies, that have the resources and interests to make it work. For example, even the adoption and the entering into force of this Convention would have been, if not impossible, at least, difficult, without the immense lobbying of two powerful states, namely France and Canada.

Several legal provisions of the TEU and the TFEU, as modified after Lisbon Treaty, could serve as arguments, in particular for the abovementioned concerns: Articles 3 (5), 21 of the TEU and to Article 167 of the TFEU (former art. 151 of TEC), Articles 207 and 216 of the TFEU. These are described below. A series of political documents could be also added.

Article 3(5) of the TEU regulates the EU's way of action in its external relations, with third countries and with the international community, in general: "in its relations with the wider world, the Union shall uphold and promote its values and interests abroad and contribute to the protection of its citizens". Some of the values referred to in Article 3 are the linguistic and cultural diversity or

33 Bogdandy, supra note 13 at 241. 
the protection and development of cultural heritage (which were first mentioned by the Constitutional Treaty). Other useful values listed through these provisions are the protection of human rights and the strict respect and development of international law.

Continuing with the same approach, Article 21 of the TEU (especially, point $\mathrm{h}$ ) points out the way in which the EU imagines a new international system. ${ }^{34}$ This system is to be based on 'multilateral cooperation' and 'global governance', which is a contrary vision to the unipolar or multipolar system and points out the intention of the EU to get involved in the 'global governance', in order to be able to promote its own model. Article 21 recognizes as fundamental principles of the European Union, inter alia, the respect for the universality and the indivisibility of all human rights and the respect for human dignity. These two principles are the true links to cultural diversity.

On one hand, the universality and indivisibility of all human rights, have started to become a reality, in the last two decades, due to the unprecedented developments that took place, in the field of economic, social and cultural rights. ${ }^{35}$ The respect for human rights in general, including the rights of persons belonging to national minorities or indigenous groups are, according to Article 4 of the UNESCO Declaration on Cultural Diversity guarantees for the

34 I.GÂlea, TRATATELE UniUniI EUROPENE. COMENTARII ŞI EXPLICAȚII EUROPEAN UNION'S TREATIES. COMMENTARIES AND EXPLANATIONS 65 (C.H. Beck, Bucharest, 2012).

35 L.-M. CRACIUNEAN, PROTECȚia DREPTURILOR CULTURALE ÎN DREPTUL INTERNAȚIONAL (C.H. Beck, Bucharest, 2011); L.-M. Crăciunean, About Cultural Rights in International Law. Conceptual Clarifications, in Romanian Journal of International Law, 70-91 no. 12/2011; Y. M. Donders, Towards a Right to Cultural Identity?, SCHOOL OF HUMAN RIGHTS RESEARCH SERIES (Vol.15 Intersentia, Antwerp-Oxford- 2002); Y. Donders, Do Human Rights and Cultural Diversity Make a Good Match? in International and Social Sciences Journal, 199/2010 (UNESCO Blackwell Publishing, 2010); A. Eide, Cultural Rights as Individual Human Rights, in ECONOMIC, SOCIAL and Cultural Rights: A TeXtBoOK 291 (A. Eide, C. Krause, A. Rosas eds., $2^{\text {nd }}$ ed. Dordrecht, Martinus Nijhoff, 2001). 
respect of cultural diversity. ${ }^{36}$ The same Declaration, in Article 5 Cultural rights as an enabling environment for cultural diversity, states that 'cultural rights are integral part of human rights, which are universal, indivisible and interdependent' and that the flourishing of cultural diversity needs "the full implementation of cultural rights as defined in Article 27 of the Universal Declaration of Human Rights and in Articles 13 and 15 of the International Covenant on Economic, Social and Cultural Rights".

On the other hand, human dignity is actually the link between the two categories of rights, as the full respect for human dignity is associated with the respect and the protection of all the rights belonging to a human being, be those rights civil and political, economic or social and cultural. Human dignity also means the obligation not to invoke cultural diversity as an excuse to infringe upon human rights, as regulated in international law, nor to limit its scope of application.

Article 167 of the TFUE establishes EU's obligation to promote respect for cultural aspects in both its external and internal relations, not only with respect to cultural agreements but also with respect to its commercial policies and sustainable development. In this way, Europe should make its own contribution to the creation and development of a new international system. Article 167 (4)of the TFUE [former article 151 (4) of TEC] is considered as an equivalent to the horizontal clause, ${ }^{37}$ regarding culture and cultural diversity, because according to its dispositions, while legally regulating in conformity with some other dispositions (including treaties in those fields in which the EU has exclusive competence),

36 UN Educational, Scientific and Cultural Organisation (UNESCO), UNESCO Universal Declaration on Cultural Diversity, art. 4, 2 November 2001, available

at: http://www.refworld.org/docid/435cbcd64.html (Article 4's marginal formula is - human rights as guaranties of cultural diversity).

37 J.Y. Carlier, Regional Integration and Cultural Diversity: the Case of European Citizenship, in CUlTURAL DIVERSITY AND THE LAW: STATE RESPONSES From AROUND THE WORLD ; PROceEdings OF THE Colloquium "The Response Of State law To The EXPRession Of Cultural Diversity 768 (M.-C. Foblets, J. F. Gaudreault-DesBiens, A. Dundes Rentelen eds., Bruxelles, Bruylant, 2010). 
the EU has to take into account cultural issues, in order to respect and promote the diversity of its cultures. The EU has a negative obligation to respect, and a positive obligation to promote cultural diversity, both within the Union and outside its borders. So, Article 167 has a double potential, a negative one related to the EU' $\mathrm{s}$ involvement in cultural issues and a positive one, related to the EU' $\mathrm{s}$ financial support for the promotion of culture and cultural diversity. ${ }^{38}$

In practical terms, at least until 2010, according to the study on the implementation of the Convention ${ }^{39}$ in the framework of human rights policies in the European Union in relation with third countries, through international agreements, it is exceptional to find situations in which these agreements contain formal clauses referring to the principles or dispositions enshrined in the Convention. For this reason, the study proposes a formula for such a formal clause and recommends its insertion in the EU's future agreements, respectively which reads as: "The application of this Agreement shall fully take into account the principles of the UNESCO Convention, 2005 on the protection and promotion of cultural expressions".

\section{Conclusion}

To conclude, the UNESCO Convention, 2005 is to be seen as being much more than a symbolic initiative, even though its symbolic nature marked and defined its adoption, and hence cannot be neglected. Despite the 'general language' of the Convention, in terms of its objectives and policies which makes its direct effects within the EU legal system impossible, with the main consequence is that there is a wide margin of appreciation in the choices of implementation and that the full effect in the EU legal order is bound by the adoption of both policies but also legislative

${ }^{38} \mathrm{Id}$. at 767-768.

${ }^{39}$ Directorate General for Internal Policies, European Parliament, Brussels, 2010, Report Implementing the UNESCO Convention of 2005 in the European Union (No. IP/B/CULT/IC/2009_057) Brussels, 227-229, http:/ / www.europarl.europa.eu/RegData/etudes/etudes/join/2010/4 38587/IPOL-CULT_ET\%282010\%29438587_EN.pdf. 
measures - there are a series of instruments that the EU can use to achieve its integration goals. Moreover, the implementation of the UNESCO Convention of 2005 has to be understood as an on-going process.

So, even if the implementation of the Convention in EU' s internal policies has timidly started and the Convention has had more of an impact on the 'political discourse' that it has had on the legislative process, there are a series of ways of action through which the implementation could be done. For example, through the EU judiciary, the ECJ, by means of consistent interpretation and use of cooperation principle. So, practically the EU 'can act for the protection of cultural diversity if it wishes to do so'.40

In respect of EU' s external relations, the change of paradigm, from cultural exception to cultural diversity, will be useful for the way in which the EU associates itself with the very idea of cultural diversity and illustrates the new role of cultural diversity at the international level. It also represents an ideological change and goes beyond an 'economic' vision of culture. ${ }^{41}$

Positively speaking, even if the scope of application of the UNESCO Convention, 2005 is narrower than the UNESCO Declaration of 2001, there are several dispositions that are linked with human rights and cultural diversity, namely: (1) the double nature of goods and services, both economic and cultural, referred to in the Preamble, as cultural goods convey identities, values and meanings; (2) the role of human rights, in general, and of cultural rights, in particular, when it comes to the protection of cultural diversity [Article 2 (1) ${ }^{42}$ and (3) the principle of sovereignty

40 de Witte, supra note 7 at 224.

41 D. Ferri, Study Paper 4A: Legal Aspects of the Implementation of the UNESCO Convention in EU Policies in Report Implementing the UNESCO Convention of 2005 in the European Union 221-227 No. IP/B/CULT/IC/2009_057, 2010.

42 ("Cultural diversity can be protected and promoted only if human rights and fundamental freedoms, such as freedom of expression, information and communication, as well as the ability of individuals to choose cultural expressions, are guaranteed. No one may invoke the provisions of this Convention in order to infringe human rights and fundamental 
[Article 2 (2)], ${ }^{43}$ that can be useful for the promotion and protection of cultural diversity.

One also has to acknowledge, that exactly the narrow scope of application presents the risk that this treaty will be reduced to a loudspeaker for sterile cultural monologues of rich democracies. ${ }^{44}$ Moreover, the approach taken in respect of the principle of sovereignty [Article 2 (2)] 45 is double faceted. Firstly, the Convention provides for the Parties' sovereign right to undertake measures on cultural policy and incentives for the Parties to engage in the promotion of the diversity of cultural expressions in their territory and this may led to the conclusion that, at the national level, dominant cultures will be the ones which will be promoted. Secondly, the aforementioned conclusion could be perfectly valid at the EU level where 'the united in diversity model' will be shaped solely by the most vocal democracies.

freedoms as enshrined in the Universal Declaration of Human Rights or guaranteed by international law, or to limit the scope thereof").

43 ("States have, in accordance with the Charter of the United Nations and the principles of international law, the sovereign right to adopt measures and policies to protect and promote the diversity of cultural expressions within their territory").

${ }^{44}$ Directorate General for Internal Policies, European Parliament, Implementing the UNESCO Convention of 2005 in the European Union (no. IP/B/CULT/IC/2009_057) 49, 2010, Brussels, http:/ / www.europarl.europa.eu/RegData/etudes/etudes/join/2010/4 38587/IPOL-CULT_ET\%282010\%29438587_EN.pdf.

45 ("States have, in accordance with the Charter of the United Nations and the principles of international law, the sovereign right to adopt measures and policies to protect and promote the diversity of cultural expressions within their territory"). 